\title{
CONTENTS
}

Foreword by Thomas A. Kochan vii

Acknowledgments

1. Paradoxes, Anomalies, and Hypotheses 1

2. Union Density in a Cross-National Context 10

3. The Evolution of Trade Unions in the United States and 29 Canada: The Emergence of the Gap in Union Density

4. Social Democratic Canada versus Free Market United 61 States?

5. Attitudes and Values: An inverted Relationship 77

6. Frustrated Demand: More Americans Want to Join Unions 93

7. The Contribution of States and Provinces to the 103 Cross-Border Unionization Gap

8. Unions among Professionals and Other White-Collar 118 Workers in the United States

9. Unions among Professionals and Other White-Collar 145 Workers in Canada

10. Estimates of Nonunion Employee Representation: 162 How Different Are the Two Countries?

11. The Legacy of Differing Cultural and Political Histories on Unionization 
Appendix A

Union Membership and Union Density Estimates:

178

Methodology and Comparability

Appendix B

Transcript of Survey on Attitudes toward Work

180

Notes

205

References

211

Index

221 


\section{Paradoxes, Anomalies, and Hypotheses}

\section{Paradoxes}

This book deals with unions and labor relations in Canada and the United States. The rationale for the book can be found in the two diagrams that follow: one showing the dramatic divergence that has developed in the percentage of employees belonging to unions in the United States and Canada and the other showing the percentage of people who approve of unions in both countries. Figure 1.1 shows how over the past four decades a huge gap in the extent of union representation has emerged between the two countries. In 1963,29 percent of employees in each country were union members (Kumar 1993). By 2001, however, only 14 percent of employees belonged to unions in the United States compared to 30 percent in Canada. Figure 1.2 displays the results of cross-national surveys for the past fifty years showing that Americans approve of unions far more than Canadians do. Although a majority of people have approved of unions in both countries (except for 1982 and the Anti-Inflation Board years of 1976 and 1978 in Canada), U.S. approval has exceeded Canadian approval in most years from 1941 to 2001 , in some cases by as much as 18 percentage points. The few exceptions are close to the margin of error.

How can we explain this paradox? Why do Americans approve of unions more than Canadians, yet since the mid-1g6os have joined unions to a much lesser extent? Indeed, how do we explain that even in Canada twice as many people approve of unions as join them, and in the United States approval of unions exceeds membership by more than fourfold?

Although these questions seem daunting enough to be the subject of a book unto themselves, there is also a second paradox to be explored. A 


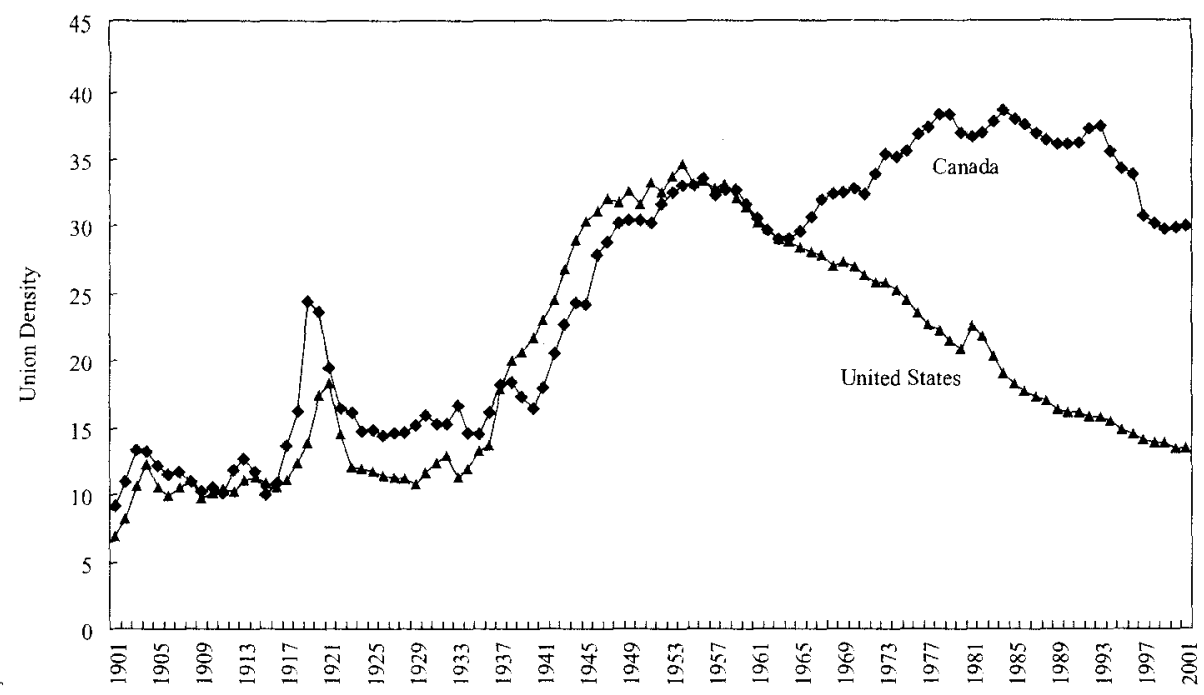

FIGURE 1.1

Union density in Canada and the United States, 1901-2001. (For data sources and methodology see app. A.)

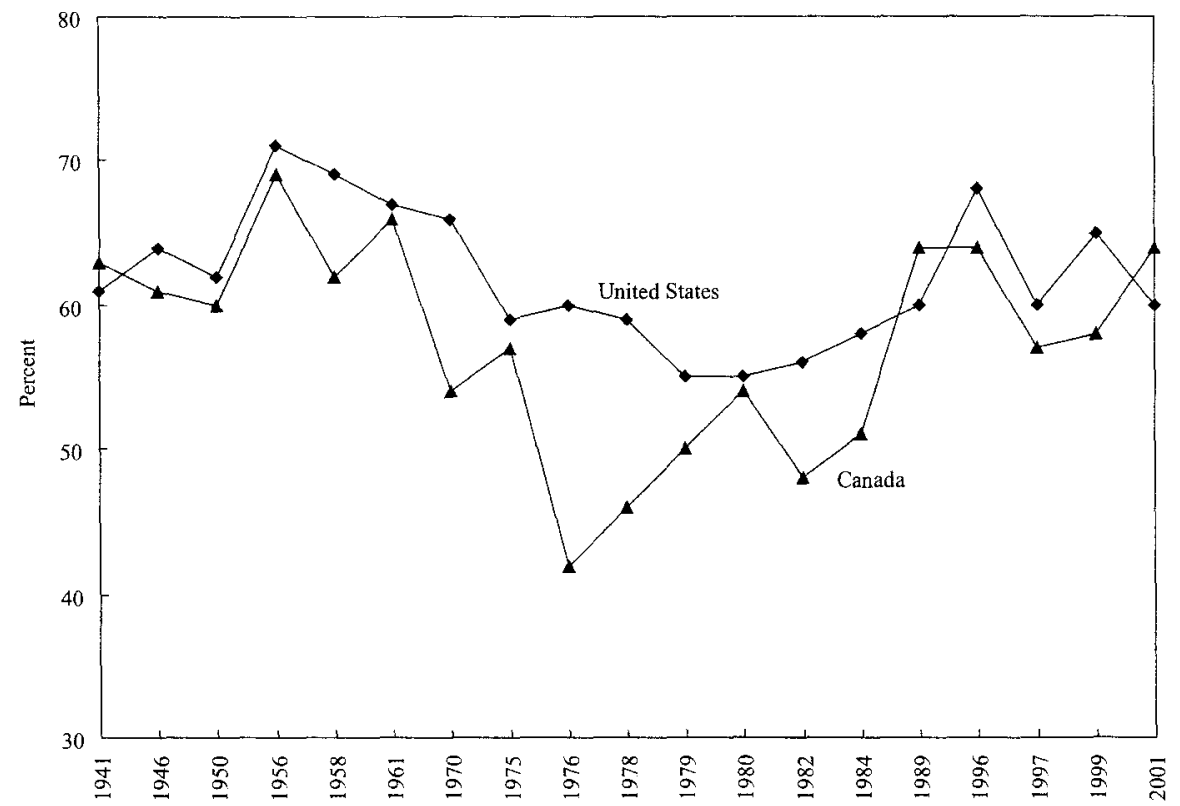

FIGURE 1.2

Union approval in Canada and the United States, 1941-2001 (Source. Gallup Poll, http://www.gallup.com.) 
survey conducted for the authors suggests that U.S. managers are less resistant to union organizing than Canadian managers (see app. B for a description of the survey). This, like the general survey data already discussed, seems counterintuitive. One of the major explanations that has been offered for lower union membership in the United States is that management is much more aggressive in opposing unions than is management in Canada (e.g., Kochan, Katz and McKersie, 1994; Gomez, Lipset, and Meltz 2001). In the United States there is even a highly visible industry providing advice to companies on how to avoid being unionized. Should we conclude that the results of the surveys are not to be trusted? We do not think so. Instead we believe that there are answers to these paradoxes, but in order to resolve them we have to probe more deeply into the factors that distinguish Americans from Canadians.

\section{The Not-So Invisible Border}

Americans and Canadians often refer to the world's longest undefended border that separates them as an invisible border. At a superficial level, there is some truth to this statement because there are few obvious differences between the two countries. In fact, Canada's largest city, Toronto, is the third largest location for filming movies in North America, after Los Angeles and New York, and, along with Vancouver and Montreal, often substitutes for almost any U.S. city. Until recently, Vancouver was even the location for the popular U.S. television program The XFiles. However, as Lipset (1990) has shown previously, there are significant differences lying below the surface in many of the attitudes and values of Americans and Canadians. In this book, we plumb these differences to see whether they contribute to the union representation gap between the two countries and, if so, how.

This is not the first book to offer an explanation for divergent unionization trends in Canada and the United States. Since 1983 many studies have suggested various reasons for the large gap that has emerged in the extent of union membership between the two countries. A full list of these factors is discussed later, but among those that are considered to have the greatest impact are labor laws and the nature and extent of the enforcement of those laws by labor relations boards. What is not considered as important are the differing attitudes and values of Americans and Canadians that in large measure underpin these same laws and legal institutions. To quote an expert analyst of the differences, "There is no 
empirical support for the hypothesis that the Canada-U.S. gap in union coverage is due to differences between the two countries in the underlying social attitudes toward unions" (Riddell 1993, 143). We hope to convince our readers that there is indeed a relation between attitudes and the extent of unionism, and that to locate it we must look beyond simple attitudinal responses and instead examine the value systems of both countries.

\section{Anomalies}

Consider figure 1.1, which tells us about trade union membership in Canada and the United States in the twentieth century. The figure shows that both countries followed similar paths for the first half of the century. Canada was somewhat ahead of the United States in union membership rates during the first three decades of this century, and then the United States led Canada from the late 193 os to the late 195os. But apart from these broadly congruent patterns, there are also some noticeable differences.

Both countries experienced a surge in membership during World War I, but after that war ended, the U.S. membership rate dropped back to prewar levels, whereas the decline in Canada was relatively less dramatic, leaving the Canadian unionization rate at a much higher plateau than in the prewar period. Figure 1.1 also indicates that for the entire twentieth century, with the exception of only one or two years, the only period in which the United States had a higher union density rate (that is, proportion of employed who are members) was during the period $1938-55$, years that included the end of the Great Depression of the 1930s, World War II, and the early postwar period-the heyday of the New Deal.

Could it be that the exception proves the rule-that it took the extraordinary conjunction of the Depression, government encouragement by the New Deal administration of Franklin Delano Roosevelt, and the greatest war in history to boost unions in the United States? This interpretation suggests that the dramatic growth of unions in the 193 os through the early postwar period may have been an anomaly. This is no way negates the fact that even today pockets of union strength exist in the United States. The success of unions such as the Auto Workers, the American Federation of Teachers and the National Education Association, the Service Employees Union, and the Teamsters brings the labor movement to more than 16 million workers. But, in relation to the work force as a whole, the union sector has been continually eroding since the mid-1950s and especially after the late 1970 s 
when the actual number of union members stopped growing and began to decline. Private-sector union membership in 2001 was 9.0 percent, lower than the rate preceding World War I. In Canada the comparable statistic in the first half of 2001 was twice as high at 18.1 percent.

If the dramatic growth of unions in the United States for almost two decades, beginning in the Depression, is an anomaly, why did it occur? Does this mean that in the United States, but not in Canada, the share of the workforce in unions increases only during wartime or peaceful periods when there is strong government support? And are the workers who join unions in Canada the same kind who belong to unions in the United States or are there major differences? These questions are the subject matter of this book.

\section{Four Hypotheses}

Central to our argument are four hypotheses about the U.S. labor movement that arise from sharp contrasts with Canada, which (even aside from geographical proximity) resembles the United States economically and socially more closely than any other country.

1. Although the experience of the Great Depression pushed both the United States and Canada toward the political left, Canada's strong social democratic movement took root in a preexisting statist, communitarian tradition. In the United States, the statist and communitarian values that emerged during the Depression and lasted into the postwar years declined under the impact of postwar prosperity. The country soon returned to an individualistic state tradition that was not supportive of collectivist approaches. The first hypothesis, therefore, is that the surge in union membership relative to labor force growth in the United States from 1938 to $195^{8}$ was an anomaly in the overall U.S. experience with unionism, as was the increase in union membership during World War I.

2. If these gains were indeed an anomaly, how do we explain the apparently high levels of public approval of unions? Union approval is high across all fifty states, but a big majority express little confidence in unions, less than for business (see Lipset and Schneider 1983). There is historical and comparative evidence that approval of unions tends to be negatively related to the perceived power of unions; that is, the weaker unions are, or at least appear to be, the more they are endorsed as an institution that is 
speaking for the interests of working people. This phenomenon has been noted in the United Kingdom and Australia as well as in North America. Public approval of unions has increased as their numerical strength has fallen. The second hypothesis is that, ironically, the greater historical approval of unions in the United States is a result of the union movement's relative weakness. We suggest that if unions were relatively stronger, as in Canada, public support would be lower.

3. Evidence suggests that for the past several decades it has been more difficult to join a union in the United States than in Canada because the underlying government institutions in the U.S. labor field-both the labor legislation and enforcement of the legislation-have not been as supportive of unionization as they generally have been in its northern neighbor. Our third hypothesis is that a major component of the paradox in unionism is the greater difficulty that Americans have in joining unions compared with Canadians. In other words, even though Americans express a greater desire or willingness to join unions, they cannot join as easily as Canadians, thereby perpetuating the weakness of the union movement and leading to an ingrained rooting-for-the-underdog syndrome.

4. One final perplexing question still remains: If U.S. citizens really are more desirous of unions and are prevented by state policies, why do U.S. governments not change their behavior? The difference in culture and values between the United States and Canada, we argue, is what contributes significantly to limitations in political and legal support for unions in the United States. Our fourth hypothesis is that in the choice between freedom for the individual and collective rights for the group, more weight is given to the individual than to the collective in the United States, except in extreme circumstances. Our fourth hypothesis also states that in Canada, compared to the United States, more emphasis is placed on the common good than on individual freedom. It is no accident, we argue, that the U.S. Declaration of Independence speaks of an individual's "... right to life, liberty and the pursuit of happiness," whereas the Canadian Constitution speaks of "peace, order and good government."

The evidence presented in this book clearly suggests that Americans do want to join unions. Impeding them from joining is the U.S. emphasis on individual freedom, combined with the peculiarities of Congressional government which make changes to labor law very difficult. This has led the United States to maintain institutional barriers against unions. These barriers have only broken down in extraordinary circumstances, such as those occasioned by wars and depressions. 
In subsequent chapters we probe U.S. and Canadian views on a range of subjects related to work, social values, and political institutions to try to understand the apparent paradox that Americans approve of unions more than Canadians do but join them less. The results are based, in part, on an in-depth survey of over three thousand people, mostly employees, conducted exclusively for the authors in the two countries.

\section{Structure of the Book}

The book is organized into eleven chapters. Chapter 2 provides an international context for the analysis by examining trends in union membership in industrialized countries in western Europe, Australia, New Zealand, and Japan, along with the United States and Canada. The data in some cases go back to 1900 . The main finding that emerges from this crosscountry evidence is that support for unions is associated with social democratic strength.

Chapter 3 presents a historical overview of the evolution of trade unions in the United States and Canada from 1901 to 2001 . Six subperiods are discussed: $19^{01-16}, 19^{16-} 3^{6}, 193^{6-5} 5^{6}, 195^{6-81}$, and $19^{81-2001}$. The focus is on the patterns of change in union membership in the two countries measured against the background of changes in the structure of the labor movements, in labor legislation, and in the political context in which these developments took place.

Three main observations emerge from this analysis. First, union density has traditionally been higher in Canada, except for the period of the New Deal (from the late 193 os to the late 1950 ). Second, the turning points in union membership in both countries are associated with significant political, social, and economic events-including wars, depressions, and changed social attitudes-that caused a shift toward the rights of workers being represented collectively in bargaining. In terms of Canadian-U.S. patterns, the major finding in this context is the much greater freedom that public-sector workers were given in Canada after the mid-196os to bargain and even strike. A final factor that affected private-sector workers and the extent of union organizing and management opposition to unions was the difference in labor legislation and its enforcement, which in Canada was more union friendly.

Chapter 4 continues the discussion of the social, political, and economic factors that underlie the more robust legislative protection and the much 
greater strength of unions in Canada than in the United States. It begins with the examination of the results of our survey. The focus is on measures of political culture in the two countries and how they differ, specifically after the mid-196os when trade union membership in the two countries parted ways. As a summary statement, it can be said that the ethos in the United States is one of individualism and an appeal to exit, as opposed to voice, as a means of protecting workers. In Canada, the underlying dominant view is still largely a social democratic one.

Chapter 5 explores our two paradoxes. The first is the central paradox of this book, that Americans approve of unions more than Canadians, but are less likely to join. The second paradox is both counterintuitive and counter to what most researchers in industrial relations believe: U.S. managers are less hostile to unions than are Canadian managers. Our analysis is based not only on what workers and managers in the two countries say about unions, but on the broader societal attitudes and values that our survey reveals. The findings of this chapter corroborate the extent of frustrated demand for unions that is examined later in chapter 6 . But this chapter also qualifies the extent of demand for unionization and differences in managers' attitudes toward unions.

Chapter 6 uses the results of our survey to measure the extent to which there is a frustrated demand for union membership in the United States. Using all the ways in which demand by workers to join unions could be determined, one finding is absolutely clear: far more Americans want to join unions than actually belong. More Canadians also want to join unions than are members, but it is on the U.S. side that the extent of frustrated demand easily outstrips observed membership rates.

Chapter 7 considers Canadian-U.S. union differences not from an aggregate perspective but rather from differences in union density within each country. What is most surprising is that differences within each country, particularly within the United States, are far greater than are the differences in the extent of union membership between the two countries. A worker in New York state, for example, is seven times more likely to belong to a union than a worker in North Carolina. That same worker in New York is about five times more likely to belong to a union than the average worker in Texas. Almost the same union density differences apply in other high-density states such as Washington, Oregon, Alaska, and Hawaii. One possible reason for these large interstate differences emerges when we look at a map. As we see in chapter 7 , the map reveals that the closer a state is to the Canadian border, the higher the probability that its 
workers will be unionized. Is this a coincidence or is there some shared set of values between border provinces and states?

Chapters 8 and 9 examine the attitudes and behaviors of white-collar workers and professionals toward unions in the United States and Canada. These populations are extremely important not only as occupations that have been recent sources of strength for unions in both countries, but also because their size and the changes that are taking place in the knowledge economy provide measures that are harbingers for the future development of unions on both sides of the border. This is part of the shift to a postindustrial society and the decline in industrial work. The key for unions is seen to be the combination of desire for representation and special needs for professional development.

Chapter 10 looks at the location and extent of nonunion employee representation. The issue we raise is whether nonunion forms of employee representation are substitutes for, or complements to, formal union representation. We find that a surprisingly high proportion of workers have nonunion representation. In fact in the United States the proportion of workers with such representation, 11 percent, is almost as great as the 14 percent who belong to a union (if we add the additional 2 percent of workers who are covered by a collective agreement). The proportion of employees covered in Canada by nonunion organizations is similar to the United States (1o percent), but of course this is only one-third of the total union representation. The differences that do exist between the two countries are explored, setting the stage for a discussion of what this means for employee representation in the future.

Chapter 11 sums up the explanations for the paradoxes that have been observed in union representation in the United States and Canada. It asks whether, on the basis of this study, the future holds a turnabout in union representation in the United States or whether, instead, Canada is destined to decline to U.S.-style levels of union membership. 


\section{Union Density in a Cross-National Context}

This book deals primarily with the sources and consequences of the sizable variation in union density and coverage between U.S. and Canadian unions. In this chapter we provide an international context in which to analyze the variation in union density between the two countries. After first comparing differences in union density and collective agreement coverage across twenty-four industrialized countries, we then examine the factors affecting cross-national variation in union density.

\section{Patterns of Union Density in Advanced Western Countries}

Union density varies greatly among the different cultural and geographic groupings of advanced Western countries. The range, using international data from the mid-1990s, is from 88 percent in Sweden to $10-14$ percent in France and the United States. French unionism is actually much stronger than this estimate of low membership suggests. ${ }^{1}$ For collective bargaining coverage, that is, the proportion of employees represented by unions, France is close to the top, 95 percent, while the United States is at the bottom, 16.7 percent. Canada is much more unionized, with 37 percent density and 40 percent coverage, clearly much more than its southern neighbor but less than much of Europe (tables 2.1 and 2.2). 
TABLE 2.1

Union Density and Collective Bargaining Coverage in the Mid-1990s (\%)

\begin{tabular}{|c|c|c|}
\hline Country & $\begin{array}{l}\text { Union Density, Dependent } \\
\text { Labor Force, } 1995\end{array}$ & $\begin{array}{l}\text { Collertive Bargaining } \\
\text { Coverage, } 1990 \mathrm{~s}^{\mathrm{a}}\end{array}$ \\
\hline Northern European countries & 76.6 & 78.8 \\
\hline Sweden & 87.5 & $85.0(1995)$ \\
\hline Iceland & 83.3 & n.a. \\
\hline Finland & 79.6 & $95.0(1995)$ \\
\hline Denmark & 77.0 & $69.0(1994)$ \\
\hline Norway & 55.4 & $66.0(1996)$ \\
\hline Low countries & 40.2 & 85.0 \\
\hline Belgium & 52.9 & $90.0(1994)$ \\
\hline Luxembourg & 43.4 & n.a. \\
\hline Netherlands & 24.3 & $80.0(1996)$ \\
\hline German-speaking countries & 31.1 & 79.3 \\
\hline Austria & 40.7 & $98.0(1994)$ \\
\hline Germany & 29.1 & $90.0(1996)$ \\
\hline Switzerland & 23.6 & $50.0(1993)$ \\
\hline English-speaking countries & 33.2 & 47.0 \\
\hline Ireland & 52.3 & $90.0(1994)$ \\
\hline Canada & $37.0^{\mathrm{b}}$ & $40.0(1994)$ \\
\hline United Kingdom & 36.4 & $47.0(1994)$ \\
\hline Australia & 35.2 & $65.0(1995)$ \\
\hline New Zealand & 24.3 & $23.1(1995)$ \\
\hline United States & 14.2 & $16.7(1995)$ \\
\hline Southern European countries & 23.4 & 84.2 \\
\hline Italy & 38.5 & $83.0(1993)$ \\
\hline Portugal & 25.6 & $71.0(1993)$ \\
\hline Greece & 24.3 & $90.0(1994)$ \\
\hline Spain & 18.2 & $82.0(1996)$ \\
\hline France & 10.3 & $95.0(1995)$ \\
\hline Ontliers & 23.5 & n.a. \\
\hline Japan & 24.0 & $25.0(1994)$ \\
\hline Israel & 23.0 & n.a. \\
\hline
\end{tabular}

Source: Daily Labor Report (Jan. 29, 1997); Ebbinghaus and Visser (2000); International Labour Organisation ([ILO] 1997, 248); Organization for Economic Development and Cooperation ([OECD] 1997); Traxler $(1996,274)$.

Note: The density data for Japan, Australia, and New Zealand (ILO 1997) are not adjusted. The 1994 density data for Canada (OECD 1997) have a coverage rate somewhat higher than the density data for Sweden, Denmark, and New Zealand. This discrepancy can be attributed to the fact that the estimates are obtained from different sources and refer to different years (see OECD 1997, 72, 84).

"n.a., not available. "For 1994.

\section{Cultural and Geographic Groupings}

The proportion of workers organized is highest in the northern European countries. Union density in these nations exceeded 75 percent in 1995 . It 
TABLE 2.2

Union Density in Developed Countries, 1950-1995, Ranked by 1995 Estimates

\begin{tabular}{lllllll}
\hline Country & $1950^{\mathrm{a}}$ & 1960 & 1970 & 1980 & 1990 & 1995 \\
\hline Sweden & 67.3 & 70.7 & 66.6 & 78.2 & 82.4 & 87.5 \\
Finland & 29.9 & 29.3 & 51.4 & 70.0 & 72.5 & 78.8 \\
Denmark & 53.2 & 60.2 & 62.1 & 77.5 & 74.5 & 78.1 \\
Belgium & 40.2 & 40.7 & 42.3 & 56.6 & 56.7 & 59.8 \\
Norway & n.a. & 51.6 & 50.0 & 54.1 & 53.1 & 52.5 \\
Ireland & 38.9 & 45.8 & 54.2 & 57.4 & 48.2 & 44.4 \\
Austria & 57.9 & 57.8 & 55.4 & 50.8 & 45.2 & 38.9 \\
Canada & n.a. & 28.3 & 29.8 & 36.0 & 36.0 & $37.0^{\text {b }}$ \\
Australia & n.a. & 49.1 & 44.4 & 48.0 & 41.0 & 35.2 \\
Italy & 40.3 & 22.4 & 34.0 & 44.4 & 33.6 & 32.4 \\
United Kingdom & 44.1 & 44.3 & 48.6 & 52.8 & 40.1 & 32.2 \\
Germany & 33.9 & 34.2 & 31.8 & 33.6 & 29.9 & 26.5 \\
New Zealand & n.a. & 54.0 & 46.1 & 56.0 & 45.0 & 24.3 \\
Japan & n.a. & 32.2 & 34.5 & 31.0 & 25.0 & 24.0 \\
Netherlands & 42.0 & 41.0 & 36.0 & 32.4 & 22.3 & 22.9 \\
Switzerland & n.a. & n.a. & 29.9 & 30.7 & 26.3 & 22.7 \\
United States & n.a. & 28.9 & 25.9 & 22.0 & 16.0 & 14.2 \\
France & 30.2 & 19.2 & 21.0 & 17.1 & 9.2 & 8.6 \\
\hline
\end{tabular}

Source: Ebbinghaus and Visser (2000); OECD (1997); ILO (1997); Visser (1994, 1993 ).

Note: Percentage of employed wage and salary earners. The 1980 and 1990 data for the United States, Canada (including 1994), Japan, Australia, and New Zealand (OECD 1997) and the 1995 data for these countries (ILO 1997) are not adjusted.

a n.a., not available.

'For 1994.

is 88 percent in Sweden, 83 percent in Iceland, $79-80$ percent in Finland, and $77-78$ percent in Denmark. ${ }^{2} \mathrm{~A}$ smaller proportion, but still more than one-half of wage and salary workers or the dependent labor force $(53-55$ percent), is unionized in Norway (see tables 2.1 and 2.2). With the exception of Finland, the northern countries form a culturally uniform group.

Union density in the nations with populations of European origin and that have been part of the British Commonwealth is much lower than in northern countries. Ireland is the most unionized of this group, with about one-half of the dependent labor force $\left(5^{2}\right.$ percent), or 44 percent of the gainfully employed, unionized compared to $3^{2-3^{6}}$ percent in the United Kingdom. The membership rates in Australia and Canada are similar to that of Britain-in Australia it is more than one-third (35 percent), and it is about the same in Canada-while the rate in New Zealand is lower at one-fourth (24 percent). The United States is the lowest, with only oneseventh (14 percent) of its wage and salary earners as union members. Collective bargaining coverage, the other measure of union strength, is low 
in English-speaking countries compared with the other regional culture groups. With the exception of Ireland and Australia, the rate in the English-speaking world is less than one-half, while in all other countries for which data are available, except Japan, it ranges from $5^{\circ}$ to 95 percent (table 2.1).

Union densities in the Low Countries, German-speaking nations, and southern European nations, plus the outliers, Japan and Israel, are also lower than in northern European countries. However, there is significant variation among them. More than one-half of the dependent labor force or gainfully employed workers $(53-60$ percent) are union members in Belgium. In contrast, union density in Luxembourg is 43 percent and in the Netherlands the rate is less than one-quarter (23-24 percent) (see tables 2.1 and 2.2).

Austria leads the German-speaking nations with about two-fifths of the dependent labor force (41 percent), or of the gainfully employed (39 percent), as union members as of 1995 . In Germany, the density figures are slightly over one-quarter (27-29 percent). In Switzerland, which is over two-thirds German-speaking, fewer than one in four workers (23-24 percent) belong to unions.

The southern European countries are culturally Latin and Catholic, with the exception of Greece. In Italy, about one-third of gainfully employed workers (32 percent), or the dependent labor force (39 percent), belongs to labor unions. In contrast, the union membership rate in France is much lower, 9-10 percent. One in four ( 26 percent) wage and salary workers in Portugal is a union member, while in Spain union density is lower-depending on the definition, 14 percent of gainfully employed workers or 18 percent of the dependent labor force belong to unions in Spain. The union membership rate in Greece is 24 percent.

Two quite different outlier industrialized countries, Japan and Israel, report similar rates, 24 and 23 percent in 1995 . In the past, the rate for the Israeli Histadrut was much higher, but it was more than a union, including many nonworkers because it provided a variety of social welfare functions, such as medical coverage and pensions. Its membership also included many pensioners. As a result, Israeli union density was estimated at 80 percent in 1979 (Wallerstein 1989,482 ). But by the mid-199os, after it gave up these functions, the unionization rate declined to 23 percent (table 2.1).

Although culture (predominantly political culture) seems to be linked to these considerable differences in union density, it has proven very difficult to order and estimate cultural variables in a fashion that permits sta- 
tistical analysis. We have, for example, no good measures of the degree of class awareness or class consciousness in various countries, unless we rely on left party voting. But, such parties themselves are too varied in ideology to be of use. In general, the cross-national analysis of union density is complicated because of the large number of independent variables and the relatively small number of countries. ${ }^{3}$ Many factors associated with cross-national variation are difficult to quantify. The unreliability of the international data also complicates statistical analysis. Measures of density and collective bargaining coverage are not always consistent and compatible because of differences in methodology and data collection. National definitions of union members and labor force measures vary. For instance, Ebbinghaus and Visser (2000) and Visser (1994) calculate union density as the ratio of union members to the dependent labor force and to the gainfully employed. The first measure includes the unemployed, but the second does not. Also the unionization estimates in some countries (e.g., the United Kingdom and Ireland) include economically inactive union members, and the comparative data on collective bargaining coverage are derived from different sources (see tables 2.1 and 2.2).

\section{Factors Affecting Cross-National Variation in Union Density}

A number of studies have looked at union density in industrialized Western countries and analyzed the factors behind cross-national and temporal variations (e.g., Ebbinghaus and Visser 1999, 2000; Golden, Wallerstein, and Lange 1999; Western 1997; Visser 1993, 1994; Ebbinghaus 1993; Blanchflower and Freeman 1992; Neumann, Pedersen, and WestergardNielsen 1991; Stephens 1991; Freeman 1990; Wallerstein 1989). Most of the studies focus on cross-national variations in union density at a given time. The historical data required for a longitudinal cross-national analysis are not always available or reliable. Nevertheless, we can report that the rank order of countries according to unionization level has remained relatively stable over the postwar period (Visser 1994, 165). The intertemporal association is also quite strong. The correlation between 1995 and $197^{\circ}$ of union densities among eighteen Organization for Economic Cooperation and Development (OECD) countries is o.8 1 (calculated from Visser's data reported in table 2.2 ).

We have analyzed the determinants of union membership rates in 1995 among the employed wage and salary earners in advanced OECD countries. The independent variables reflect various political, structural, eco- 
nomic, and religious cleavages as formulated in Lipset and Rokkan's $(1967)$ analysis of cross-national political variation. Variables identified in other studies of unionization are also included in the analysis.

The following indexes, which provide a quantitative assessment of various factors that appear to affect union density, have been used: left cumulative power (how long left parties have held national office); Catholic cumulative power (how long Catholic parties have held national office); corporatism; legal regulation of labor relations; and religious, political, and economic divisions in union systems. Our independent variables also include the Ghent system, labor force size, the proportion employed in government and private industry, the state's share of GDP revenue, the extent of ethnolinguistic diversity, and the religious composition of the population (table 2.3). ${ }^{4}$

\section{The Relationship between Left Parties and Union Strength}

Unions and left parties have been seen as different parts of same movement. Comparative analyses of labor organizations points to their varied relationships with left parties, for example, social democratic, labor, socialist, and communist. In some countries, left parties were basically an offspring of the trade union movement; in others, the labor organizations were created by the political movements or developed in parallel with them. Unions played a significant role in the founding of left parties in Great Britain and other English-speaking countries, as well as in Scandinavia. United States is the exception (Marks 1989; Western 1997,67-69). The variations in the historical patterns of union formation and partyunion relationships have been related to differences in cleavage structure (see Lipset and Rokkan 1967; Lipset 1983; Ebbinghaus 1993, 1996; Western 1997, 67-69).

Class-consciousness has traditionally been strong in the Scandinavian countries. Unions founded social democratic parties in Sweden and Denmark and the Labor party in Norway by the end of the nineteenth century. In Iceland, then a dependent territory of Denmark, the Icelandic Federation of Labor acted also as the Social Democratic Party from the time of its founding by unions in 1916 (Ebbinghaus 1996; Kjartansson 1992).

Similarly, unions were involved in the formation of labor parties in Great Britain, Ireland, Australia, and New Zealand (Western 1997, 67-69). Labor activists took part in the formation of the first electorally viable social democratic party in Canada, the Cooperative Commonwealth Federation 
TABLE 2.3

Political, Structural, and Economic Characteristics of Eighteen OECD Countries

\begin{tabular}{|c|c|c|c|c|c|c|c|c|c|c|c|c|c|}
\hline Country & $\begin{array}{c}\text { Left } \\
\text { Cumulative } \\
\text { Power, } \\
1946-94\end{array}$ & $\begin{array}{c}\text { Catholic } \\
\text { Cumulative } \\
\text { Powler, } \\
\text { 1946-94 }\end{array}$ & $\begin{array}{l}\text { Conporatism } \\
\text { Index }\end{array}$ & $\begin{array}{l}\text { Ethnolinguistic } \\
\text { Fractionalization }\end{array}$ & $\begin{array}{c}\text { Proportion } \\
\text { of Catholic } \\
\text { Population } \\
\text { (\%) }\end{array}$ & $\begin{array}{l}\text { Employed } \\
\quad \text { and } \\
\text { Unemployed } \\
\text { (millions) }\end{array}$ & $\begin{array}{c}\text { Government } \\
\text { Revenue, } \\
1995(\% \\
\text { of } C D P)\end{array}$ & $\begin{array}{c}\text { Government } \\
\text { Employment } \\
1995 \\
\text { (\% total } \\
\text { employment) }\end{array}$ & $\begin{array}{c}\text { Industry } \\
\text { Employment, } \\
1995 \\
\text { (\% total } \\
\text { employment) }\end{array}$ & $\begin{array}{c}\text { Legal } \\
\text { Regulation } \\
\text { Index }\end{array}$ & $\begin{array}{c}\text { Occupational } \\
\text { Split }\end{array}$ & $\begin{array}{l}\text { Religious } \\
\text { Split }\end{array}$ & $\begin{array}{l}\text { Political } \\
\text { Split }\end{array}$ \\
\hline Sweden & 38.86 & 0 & 1.70 & 0.065 & 1.4 & 4.27 & 57.4 & 32.0 & 25.0 & 16 & 40 & 0 & 0 \\
\hline Denmark & 26.91 & 0 & 1,60 & 0.028 & 0.6 & 2.73 & 59.1 & 30.5 & 26.8 & 16 & $2 \mathrm{I}$ & 0 & 0 \\
\hline Finland & 19.29 & 0 & 1.80 & 0.105 & 0.1 & 2.47 & 53.2 & 25.1 & 26.8 & 16 & 34 & 0 & 0 \\
\hline Norway & 36.88 & 0 & 1.80 & 0.070 & 0.3 & 2.12 & 50.5 & 30.6 & 23.4 & 16 & 18 & 0 & 0 \\
\hline Belgium & 15.87 & 26.06 & 1.30 & 0.964 & 90.0 & 4.20 & 50.8 & 19.4 & 27.7 & 15 & 0 & 0 & 53 \\
\hline New Zealand & 16.25 & 0 & 0.95 & 0.148 & 18.7 & 1.70 & n.a. & 22.1 & 24.9 & 14 & 0 & 0 & 0 \\
\hline Australia & 18.77 & 0 & 1.10 & 0.113 & 29.6 & 8.78 & 34.2 & 16.6 & 23.5 & 14 & 24 & 0 & 0 \\
\hline Austria & 30.54 & 18.05 & 1.80 & 0.033 & 88.8 & 3.88 & 47.3 & 22.4 & 33.2 & 15 & 0 & 0 & 0 \\
\hline Ireland & 4.86 & 0 & 1.15 & 0.090 & 95.3 & 1.42 & 38.9 & 13.4 & 27.6 & 11 & 0 & 0 & 0 \\
\hline United Kingdom & 16.16 & 0 & 0.95 & 0.106 & 13.1 & 28.32 & 37.3 & 14.4 & 27.7 & 11 & 0 & 0 & 0 \\
\hline Italy & 5.57 & 38.65 & 0.75 & 0.039 & 83.2 & 22.72 & 44.5 & 16.1 & 32.1 & 13 & 0 & 34 & 63 \\
\hline Germany & 12.31 & 0 & 1.40 & 0.044 & 35.0 & 39.22 & 45.9 & 15.9 & 37.6 & 12 & 13 & 3 & 0 \\
\hline Canada & 0 & 0 & 0.80 & 0.376 & 46.6 & 14.83 & 46.7 & 19.6 & 22.6 & 10 & 0 & 3 & 0 \\
\hline Switzerland & 12.50 & 13.83 & 1.40 & 0.308 & 52.8 & 3.91 & 37.4 & 14.0 & 28.8 & 14 & 17 & 13 & 0 \\
\hline Japan & 0.81 & 0 & 0.40 & 0.010 & 0.6 & 66.45 & 32.2 & 6.0 & 34.0 & 10 & 0 & 0 & 51 \\
\hline Netherlands & 11.11 & 14.02 & 1.40 & 0.063 & 42.6 & 7.12 & 51.6 & 12.7 & 23.0 & 15 & 13 & 20 & 0 \\
\hline United States & 0 & 0 & 0.85 & 0.209 & 30.0 & 1.31 .06 & 31.7 & 14.0 & 24.0 & 9 & 15 & 0 & 0 \\
\hline France & 12.59 & 3.97 & 0.60 & 0.146 & 76.4 & 24.87 & 46.8 & 24.8 & 26.7 & 12 & 22 & 4 & 55 \\
\hline
\end{tabular}

Sonure: Huber, Ragin, and Stephens (1997); La Porta et al. (1998); "OECD in Figures" (1997); Redding and Viterna (1999); Wessels (1996). 
(CCF), and played a significant role in the organization of the New Democratic Party (NDP), the CCF's successor (Horowitz 1968; Lipset 1996, 96; Meltz 1985, 326). But in contrast to other English-speaking countries, unions in the United States never created or supported their own labor or social democratic party (Lipset and Marks 2000, 85-112; Marks 1989).

Unions in Germany were formed under the influence of socialist and labor parties that later formed the Social Democratic Party (Marks 1989; Verberckmoes 1996a). Labor organizations in Austria and Finland developed in parallel with social democratic and socialist parties. In Switzerland, Belgium, and Netherlands, the ties of emerging union movements with left parties were weakened by the church-state cleavage, which led to the formation of Christian unions (see Broeck 1992; Ebbinghaus 1993, 1996; Gruner 1992; Pasture 1996; Schonhoven 1992; Soikkanen 1992; Voorden 1992). Reformist-revolutionary ideological differences fragmented organized labor in France, Italy, and Spain, countries in which the church-state cleavage was also strong. Unions in these Latin countries initially developed under the influence of syndicalists and anarchists; hence, they formed separately from socialist parties. In these nations, the power of the ideologically revolutionary anarchosyndicalists facilitated strong communist parties, with strength among unions (see Bianchi 1996; Ebbinghaus 1993, 1996; Esenwein 1992; Verberckmoes 1996b). The strength of revolutionary parties and unions in the Latin societies is related to the late development of a full-grown industrial system and state repression of working-class political and economic rights (Lipset 1983).

The differences in historical origins and links of left parties and unions affect their present relationships. Left parties that were originally formed by unions continue to have much closer organizational and political ties with organized labor (Western 1997,67-69). Scandinavian countries represent an example of this relationship (Galenson 1998). In contrast, links between left parties and unions are weaker where they emerged independently of one another.

Previous cross-national studies have reported a strong and significant relationship between the strength of left parties in government and unionization levels (see Stephens 1991; Visser 1994; Wallerstein 1989; Western 1997). Our statistical analysis indicates that the index of left cumulative power strongly correlates with union density in eighteen OECD countries. The left cumulative power index, developed by Huber, Ragin, and Stephens (1997) and based on the percentage of parliamentary seats held by left parties in government from 1946 to 1994 , correlates positively with 

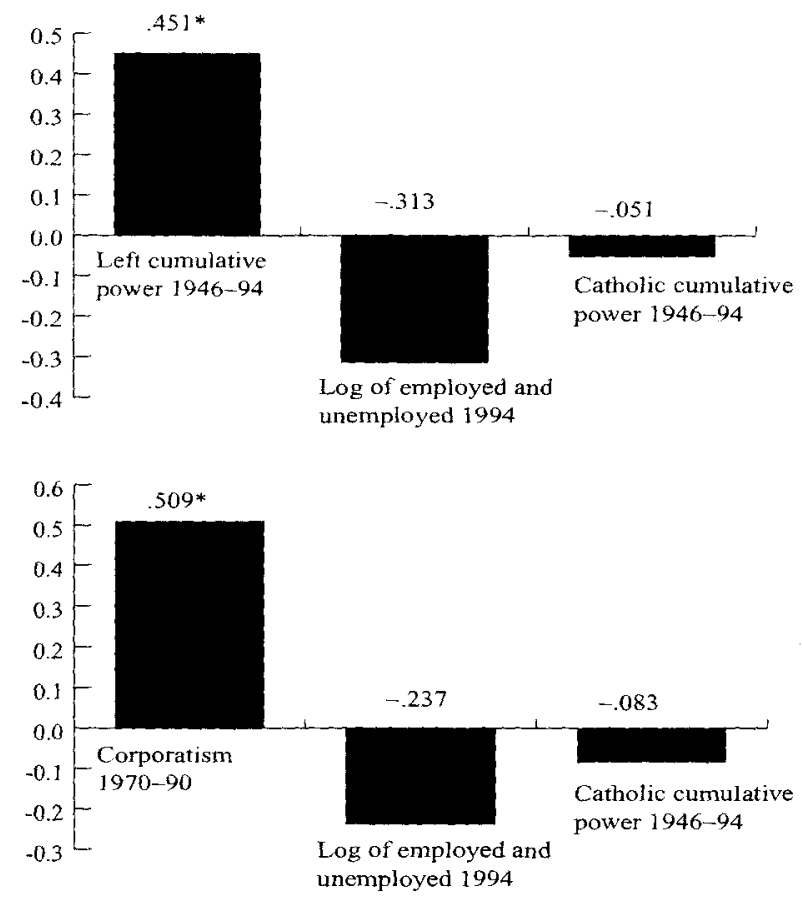

FIGURE 2.1

Determinants of union density in eighteen OECO countries, 1995 (standardized coefficients). $* p<0.10$. (For data sources see tables 2.2 and 2.3.)

union density $(0.63)$. The association holds when tested in multivariate regressions and is statistically significant at $p<0.10$ (figure 2.1 ). ${ }^{5}$

Left parties have never been represented in the national governments of the United States and Canada (table 2.3). Social democratic parties, however, have had considerable strength at the provincial level in Canada, much more than in the U.S. states. This is particularly important because provincial governments are responsible for labor legislation that covers approximately 90 percent of the Canadian work force. Since the $197 \mathrm{os}$, social democratic parties have on various occasions governed in five of the ten provinces and the territory of the Yukon. In the early 199os, three NDP governments (Ontario, British Columbia, and Saskatchewan) covered more than one-half the Canadian population, while the Parti Quebecois was the governing party of Quebec. The Parti Quebecois tried to affiliate with the Socialist International but was prevented from doing so by the NDP, which had the right to prevent another Canadian party from joining. 
Social democratic parties and labor unions clearly have been much stronger north of the border.

Beyond reflecting working-class values, social democratic strength affects the legal environment in which unions operate, a factor obviously related to union bargaining power. An index of legal regulation of labor relations is very strongly associated with the left cumulative power index (o.81). ${ }^{6}$ Left governments are more likely to provide state support for unions during conflicts, as well as union-friendly legislation. The latter, as expected, is positively correlated with union density in the eighteen OECD countries $(0.62)$.

\section{The Ghent System}

The Ghent system, in which unions are involved in administration of unemployment insurance schemes, is very favorable for unionization. This system originated in Belgium when the local governments started to subsidize unemployment funds run by unions, but its development has varied in different periods and countries. The Ghent system now exists in Belgium, Sweden, Denmark, and Finland, all of which have very high unionization rates. The other advanced Western countries have public unemployment insurance schemes (see Galenson 1998; Western 1997).

Because trade unions run unemployment insurance funds and pay unemployment benefits, many workers in these countries remain union members even when they lose their jobs. The Ghent system is also favorable to unionism because it gives unions control over labor market competition (Western $1997,55^{-} 5^{6}$ ). The Ghent system dummy variable is highly correlated with union density $(0.87)$. However, it is also associated with the cultural and geographic cluster of northern European countries to which all these nations, except Belgium, belong.

A comparison of otherwise similar countries within the same cluster with and without the Ghent system allows us to better evaluate its effect on the unionization rate. Among the Low Countries, Belgium has a much higher union density than the Netherlands. Similarly, the unionization rate in Sweden exceeds the rate in Norway, which lacks the Ghent system (see table 2.1; Western 1997, 57).

\section{Corporatism}

Some cross-national studies seek to evaluate the effect of corporatism on union density. Corporatism generally refers to systems in which business, 
unions, and government negotiate regularly with one another on economic issues. The literature focuses on varying aspects of corporatism and employs somewhat different indicators. Nevertheless, the various indexes of corporatism tend to be positively intercorrelated (see Pennings and Vergunst 2000). Our index reflects the organizational unity of labor and scope of collective bargaining in 1970-90. ${ }^{7}$ The corporatism and left power indexes are highly correlated (0.78), a finding reported by Wilensky (1981) and Western (1994). Corporatism clearly has a social democratic character.

Other researchers report that corporatism has significant positive effects on union density in advanced Western countries (Ebbinghaus and Visser 1999; Freeman 1990). ${ }^{8}$ Our corporatism index is correlated with union density ( 0.67 ); the finding is statistically significant in a regression analysis (figure 2.1). Government involvement in collective bargaining is one of the core elements of corporatism (Lange, Wallerstein, and Golden 1995, 87 ). Government and parliamentary participation in bargaining is positively associated with union density in sixteen OECD countries (Golden and Londregan 1998,7$) \cdot{ }^{9}$ Correlations between these two variables and the union membership rate in 1995 are 0.36 and 0.63 respectively.

\section{Occupational, Ethnic, and Linguistic Cleavages}

Ebbinghaus and Visser (2000) report that the differences in levels of union organization among countries are similar to a large degree to the analysis of party systems and structural cleavages of Lipset and Rokkan (1967). They also report that the strength of union movements cross-nationally are linked to the depth of the labor-capital cleavage and the extent of the status gap between nonmanual white-collar and professional employees and manual workers.

The high unionization rate in the Scandinavian countries has been attributed to the organization of white-collar and professional employees (Galenson 1998, 133). As of 1985 , white-collar union density was 79 percent in Denmark, 71 percent in Sweden, and 62 percent in Norway, compared to $5^{1}$ percent in Austria, 45 percent in Britain, 34 percent in Switzerland, 28 percent in Germany, and 25 percent in the Netherlands. ${ }^{10}$ There is a significant correlation between the overall national union membership rates and intraclass variations in union strength, $0.46 .{ }^{11}$ The measure of the latter indicates the relative strength of white-collar, professional, and other occupationally based unions (see Wessels 1996; table 2.3). 
The examination of the effects of ethnic diversity produces ambiguous results. Visser (1 994) and Stephens (1 991), as well as our own analysis, find limited support for the hypothesis that ethnic heterogeneity hampers union organizing. There is even less significant evidence of support for the linguistic diversity hypothesis. Using the ethnic diversity index employed by Stephens (1991) we find a negative, but not statistically significant, relationship with union density. Similarly, our use of an ethnolinguistic fractionalization index, derived from La Porta and colleagues (1998), does not yield significant regression results.

\section{Catholic Parties Power and Religion}

Christian Democratic party strength is associated with unionization (Misra and Hicks 1994, 304). Wilensky (1981) notes that Catholic party power is as important a source of welfare state development as left party power. Catholic-based parties favor unionization, albeit by Christian union confederations, which exist in several western European countries, but a religious confederation represents the majority of union members in only one nation, Belgium (see Ebbinghaus and Visser 2000, 46 ; Western 1997, 8o-83).

Our analysis indicates that a Catholic cumulative power index, which measures Catholic parties seats as a percentage of seats held by all government parties in 1946-94, does not significantly correlate with union density in multivariate regressions (Huber, Ragin, and Stephens 1997). The proportion of Catholics in the population is negatively related to union strength in our statistical analysis (see also Misra and Hicks 1994). Conversely, our Protestant variable is positively associated with density, that is, unions are stronger in Protestant than Catholic countries. ${ }^{12}$

\section{Economic Factors}

Our statistical analysis indicates that the size of the labor market, defined as the $\log$ of the 1994 employed and unemployed population, is negatively associated with union density in the eighteen industrialized Western countries (figure 2.1). The correlation coefficient is -0.57 . Country size is of obvious importance. It may be noted that the majority of small countries have strong labor movements: Austria, Belgium, Denmark, Finland, Iceland, Ireland, Luxembourg, Norway, and Sweden. Union density, however, is low in Greece, the Netherlands, New Zealand, Portugal, and Switzerland compared with larger countries inside their cultural areas. 
Such large countries as the United States, Japan, and Germany, have low density. Wallerstein ( 1989 ) seeks to explain the relationship by noting that in countries with larger labor markets, unions face higher costs of organizing additional union members. He points out $(1989,487)$ that union organizing is especially expensive in the United States, which has the biggest labor market in the industrialized world.

This finding that union membership rates are higher in smaller countries, however, may be a spurious one. Stephens (1991) points out that labor-force size is highly correlated with economic concentration, a variable that may be used as a proxy for industrial structure. ${ }^{13}$ Such a high correlation $(-0.90)$ in a small sample results in a multicollinearity problem. Statistical analyses are not able to distinguish the relative effect of these factors because of the very strong link between the two independent variables.

Union membership rates vary greatly among different industries and sectors of employment. In most advanced countries, it is higher in manufacturing and the public-sector than elsewhere in the economy (Ebbinghaus 1993, 186; Western 1997, 125). Curiously, measures of industrial and occupational structures, such as the proportion of wage and salary earners employed in industry (manufacturing, mining, utilities, and construction), public-sector, or blue-collar occupations, have no significant effects on union density when tested cross-nationally (Visser 1994, 177; Wallerstein 1989). Our computations also show that the proportion in industrial employment does not significantly affect the union membership rate. Estimates of trade dependence, such as the proportion of the merchandise exports in the GDP, produce similar results (Visser 1994).

The extent of government employment as of 1995 is positively correlated with union density, but our analysis indicates that this relationship is not significant when controlled for size of labor force and the left power index. The proportion of government revenues in the GDP is similarly associated with union density. These variables, of course, correlate highly with the left-party index, which leads again to a multicollinearity problem. Causation may also run in the opposite direction (Ebbinghaus and Visser 1999,148 ).

As can be seen from the results reported earlier, cross-national statistical analysis of union density in advanced Western countries has its limits. The number of countries is small and comparable data are not always available. Moreover, there are many independent structural, economic, and political 
variables that can logically be posited to affect union density. Correlations are often difficult to interpret, and as our treatment of the left power, legal regulation of labor relations, and corporatism indices illustrates, union-linked variables are often interrelated. Multivariate regressions are problematic, given the interaction between independent variables or interconnected effects.

\section{Cultural Clusters}

To reiterate, union density and collective bargaining rates vary greatly within the English-speaking and European clusters, that is among northern European, southern European, German-speaking, and the Low countries. Statistical analysis cannot account for the differences among these cultural groupings (see Ebbinghaus and Visser $1999,15^{\circ}$ ). In contrast to the other culture regions, union densities in the highly unionized northern European countries have remained stable or even increased since 1980 . Social democratic, class, and corporatist traditions and the Ghent system are especially strong in these states, all of which are small and Protestant (table 2.3). Norway is somewhat of an exception because its density and collective agreement coverage rates are significantly below the other northern European countries and it does not follow the Ghent system. There are greater absolute differences in these rates between Norway and Sweden (19 percentage points on coverage and 32 points on density) than there are between the United States and Canada (23 points on coverage and 23 points on density). In relative terms, however, the U.S.-Canadian gap is greater.

Union density differs greatly among the Low Countries. Belgium, which has the Ghent system, is the most highly organized country in the group, whereas the Netherlands has a much lower unionization rate. These two occupy the middle ground on the index of corporatism in 1970-90 (table 2.3). Belgium has the strongest Christian unions among advanced Western countries.

Membership rates also vary considerably among the southern European countries; the range between the highest, Italy, and the lowest, France, is quite large. However, collective bargaining coverage among them and the Low Countries is uniformly high (table 2.1). These two groups of countries are Catholic, with the exception of Greece, which is Orthodox, and the Netherlands, which has about equal proportions of Catholics and 
Protestants. Among the German-speaking countries, Germany and Switzerland stand in the middle of the range on density. However, Austria, the smallest country, has the highest levels of union density, coverage, and corporatism in this group (table 2.1).

Both union density and collective bargaining rates differ significantly among English-speaking countries. Union density is highest in Ireland, the smallest country in the group. Ireland has almost one and one-half times higher the unionization rate and two times the bargaining coverage of Great Britain. The same pattern of variation applies to Australia and New Zealand. Union density in Australia is almost one and one-half times higher than New Zealand, and the coverage rate is almost three times higher.

As we have stressed, the United States and Canada, two neighboring, predominantly English-speaking societies with similar economic structures, have shown considerable divergence in union density and political culture (Lipset 1996, 77-109; 1986; 1990; Meltz 1985; 1989b; 1990; Western 1997, 18). Union density in Canada in the mid-1990s (37 percent) was more then two times higher than in the United States ( 14 percent). The collective bargaining coverage rate in Canada (40 percent) also exceeds that in the United States ( 17 percent) by more than two times. Corporatism does not differentiate, given that in the English-speaking countries, including the United States and Canada, it is generally very weak.

As noted, Canada is much more social democratic in its values and social policies than the United States; the majority of its provinces and population have been governed by social democratic parties, whereas few states in the United States have. The exceptional weakness of labor unions in the United States would appear to be linked to the same factors as those related to the absence of a visible socialist or labor party (Lipset and Marks 2000). A systematic comparison of the two nations, made possible by the 1996 Lipset-Meltz survey data and qualitative and historical materials, allows us to overcome some of the methodological problems posed by the too-few-countries, too-many-variables problem that undermines statistical research. Clearly, the comparative study of variation in trade union support would benefit much by case study analyses of the variations within small national clusters (e.g., the Low and southern European countries).

The picture is somewhat different when looking at the extent of collective bargaining coverage in the advanced Western countries. The overwhelming majority of employed people in two low-density Latin countries, 
France and Spain, are covered by collective bargaining, 95 percent in the first and 82 percent in the second. A similar pattern exists in Greece and Italy. The coverage rate in Greece was 90 percent in 1994, and in Italy it was $8_{3}$ percent in 1993 .

Collective bargaining coverage is much weaker in English-speaking nations (Adams 1995). In Ireland, which is an exception to this generalization, go percent of workers are covered by collective bargaining. Collective bargaining coverage and union density, defined in terms of the dependent labor force, are closely related with one another in the United States ( 17 and 14 percent), Canada, (40 and 37 percent), New Zealand ( 24 and 23 percent), and Japan ( 25 and 24 percent). In Great Britain and Australia, the coverage rates ( 47 and 65 percent) are notably higher than densities ( 36 and 35 percent) (see table 2.1 ).

\section{The Gap between Collective Agreement Coverage and Union Density}

What causes collective agreement coverage to differ from the union membership rate? In the United States and Canada, a contract negotiated by a union certified to represent employees in a bargaining unit covers all employees in the unit, whether or not they belong to a union. Because not all employees in the bargaining unit join the union, there will be a gap between collective agreement coverage and the union membership rate. Similar factors are at play in the narrow gaps in Japan and New Zealand. Since 1980 , the relative decline in the union membership rate was largest in New Zealand (table 2.2). ${ }^{14}$ Union density in New Zealand in 1995 was less than one-half the rate in 1980 . This drop has been attributed to the deregulation of the labor market (Harbridge and Honeybone 1996). In many countries, industry sector agreements negotiated between an employers' association and union(s) are extended to cover all employees in the industry. In addition, some governments make provision for wagerate extensions. Deregulation is usually accompanied by the elimination of these industry extension provisions.

Why should any employee want to join a union and pay union dues if the industry or the government determines their terms and conditions of employment? Why not be a free rider? Although there is no statistically significant inverse relationship, if the northern European countries are excluded along with the United States, Canada, Japan, and New Zealand, there is a huge gap between coverage and density rates in a large number of countries (France, Greece, Spain, Germany, Austria, the Netherlands, 